Mr Branko Livada, major, dipl. inž.

Vojislav Babić, dipl. inž.

\section{Noćne optoelektronske sprave sa pojačivačima slike}

\section{Uvod}

Prikupljanja informacija o protivniku i prostoru u kome se izvode borbena dejstva jedna je ad aktivnosti koja najkompleksnije utiče na efikasnost izvođenja borbenih dejstava. U procesu prikupljanja informacija vrlo važnu ulogu ima primena čula vida, pri čemu je osnovni nosilac informacija reflektovano zračenje Sunca, jer je ljudsko oko maksimalno prilagođeno za rad $\mathrm{u}$ dnevnim uslovima. Noću i u uslovima snižene osvetljenosti, mogućnosti oka su znatno smanjene, pa se takvi uslovi smatraju vrlo složenim za izvođenje borbenih dejstava zbog: otežanog osmatranja i orijentacije, otežanog uočavanja ciljeva, veće verovatnoće iznenađenja i dejstava sa bliskih odstojanja, ograničene mogućnosti upotrebe i smanjene efikasnosti tehničkih sredstava, smanjene mogućnosti kretanja i manevra. Iako su uslovi za izvođenje borbenih dejstava složeni, umanjene mogućnosti vizuelnog kontakta sa protivnikom omogućavaju postizanje iznenađenja i bolju zaštićenost sopstvenih snaga. Zbog toga postoji veliki interes za upotrebom tehničkih sredstava koja omogućuju prevazilaženje nedostataka čula vida u tim uslovima.

Među sredstvima koja omogućavaju izvođenje borbenih dejstava noću i u uslovima ograničene vidljivosti naj- značajniju ulogu imaju optoelektronska sredstva (uređaji, sprave). Optoelektronska sredstva mogu biti aktivna i pasivna. Aktivna sredstva u svom sklopu sadrže veštačke izvore zračenja koje je za golo oko nevidljivo, ali se lako može pretvoriti u vidljivo pomoću prijemnika zračenja optoelektronskog uređaja. Pasivna sredstva koriste za svoj rad zračenje prirodnih izvora koje je za golo oko nevidljivo ili slabo vidljivo.

$\mathrm{Za}$ povećanje mogućnosti oka $\mathrm{u}$ dnievnim uslovima koriste se optički uređaji (sprave) uglavnom za povećanje moći uočavanja detalja (uvećanje) i/ili oplemenjivanje vizuelne informacije novim sadržajima (npr. končanica).

Zračenje noćnog neba (Mesec, zvezde) osnovni je izvor zračenja za pasivne optoelektronske uređaje sa pojačavačima svetlosti (slike).

Sopstveno »toplotno« zračenje objekata koristi se u termovizijskim uređajima.

Odnos mogućnosti dnevnih optičkih uređaja, pasivnih sprava sa pojačavačima slike i termovizijskih uređaja, izražen kroz domet u zavisnosti od nivoa osvetljaja i meteorološke vidljivosti, kvalitativno ilustruje sl. 1.

Iako termovizijski uređaji imaju znatno veće mogućnosti nego uređaji sa pojačavačima slike, zbog složene tehnologije i visoke cene imaju ograničene 
mogućnosti masovne primene, tako da aktuelnost i širina primene pasivnih sprava sa pojačavačima slike nije bitno ugrožena pojavom termovizijskih uređaja.

Razvoj aktivnih uređaja (pretvarači slike + IC farovi) počeo je tridesetih godina i praktično su korišćeni u II svetskom ratu, a intenzivno usavršavanje i opremanje jedinica ovom vrstom uređaja karakteriše period prvih dvadeset godina posle rata, ali se i danas mogu sresti u opremi jedinica. Krajem pedesetih i početkom šezdesetih godina počinje intenzivan razvoj i primena pasivnih sprava sa pojačavačima slike, a neprekidno usavršavanje teče i danas.

Iskustva iz većine lokalnih ratova u periodu posle II svetskog rata (vijetnamski rat, foklandski sukob, rat saveznika protiv Iraka) ukazuju na izuzetan značaj i mogućnosti primene tehničkih sredstava za noćna borbena dejstva.

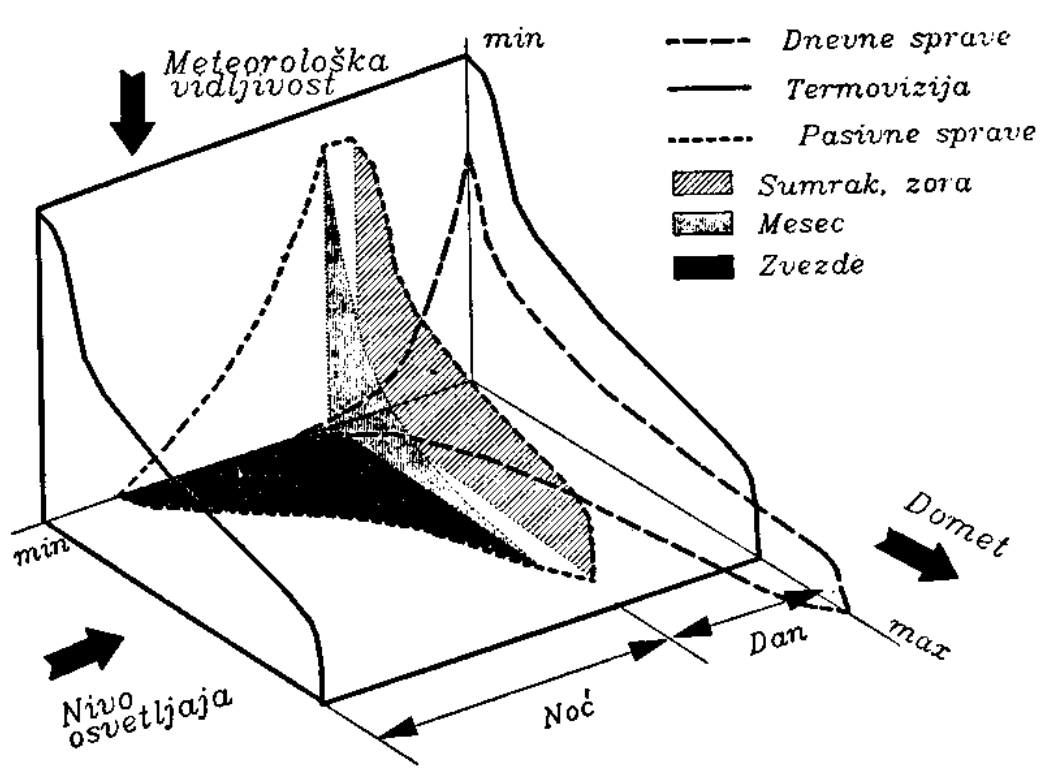

Sl. 1 Međusobni odnos mogućnosti dnevnih (optičkih) sprava, pasivnih sprava i termovizijskih uređaja

Iako su pasivni uređaji sa pojačavačima slike u operativnoj upotrebi oko dve decenije, usled relativno male rasprostranjenosti u jedinicama, specifičnosti i ukupne mogućnosti upotrebe nisu u dovoljnoj meri prisutne u taktici i obuci za izvođenje borbenih dejstava u otežanim uslovima, što za posledicu može imati nedovoljnu iskorišćenost u- kupnih mogućnosti i neadekvatan pristup u rukovanju, osnovnom i tehničkom održavanju raspoloživih sredstava, kao i neadekvatan pristup u opremanju jedinica.

\section{Fizički osnoyi primene i konstrukcije pasivnih sprava sa pojačavačima slike}

Strukturna blok-šema koja prikazuje funkcionisanje optoelektronskih uređaja sa pojačavačima slike prikazana je na sl. 2. Konstrukcija pasivnih spra-

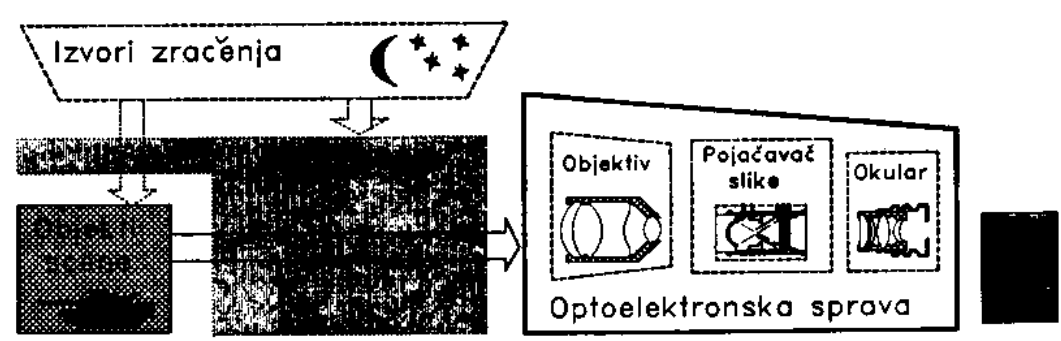

Sl. 2 Opšta blok šema upotrebe pasivnih sprava

va zavisi od namene sprave koja diktira izbor objektiva (refrakcioni, refleksioni, katadioptrički), tipa pojačavača slike i okulara (monokularni, binokularni, biokularno-fiberoptička konusna lupa). Za bolje razumevanje ukupnih mogućnosti i specifičnosti upotrebe pasivnih sprava detaljnije će se razmotriti uticaj pojedinih elemenata koji deluju na svojstva i karakteristike pasivnih sprava.

Faktori koji utiču na uočavanje objekta u osmatranoj sceni

$\mathrm{Na}$ uočavanje objekta u posmatranoj sceni, a time i na ukupne mogućnosti primene pasivnih sprava sa pojačavačima slike, utiče više faktora od kojih su najznačajniji:

- nivo osvetljenosti scene (intenzitet i spektralne karakteristike izvora zračenja);

- kontrast u sceni uslovljen refleksnim karakteristikama i geometrijom (oblik, veličina) objekta i okoline; 
- prenos kontrasta kroz atmosferu i spravu (MTF - modulaciona prenosna funkcija);

- transmisija (propustljivost) atmosfere $\mathrm{i}$ elemenata optičkog sistema sprave;

- rasejanje zračenja u atmosferi;

- relativni otvor objektiva;

ve;

- uvećanje optičkog sistema spra-

- moć razlaganja pojačavača slike

- svetlosno pojačanje pojačavača (pretvarača) slike.

Način uticaja ovih faktora prikazan je na slici 3 .

Ljudsko oko, kao krajnji prijemnik pri transformaciji slike scene primenom pasivnih sprava, registruje sliku na luminescentnom ekranu pojačavača slike koja se do oka prenosi pomoću okulara. Moć razlaganja oka kompleksno zavisi od kontrasta i luminancije posmatrane slike scene (osvetljenosti mrežnjače), što ilustruje slika 4.

Uočavanje objekata u posmatranoj sceni moguće je samo kada postoji razlika u svetlosnim signalima objekta i njegove okoline, tj. ako postoji zadovoljavajući kontrast $u$ sceni $u$ periodu trajanja vizuelnog procesa. Kontrast se definiše na dva različita načina:

$$
\begin{aligned}
& C=\frac{B_{1}-B_{2}}{B_{2}} \\
& C=\frac{B_{1}-B_{2}}{B_{1}+B_{2}}
\end{aligned}
$$

gde su:

$$
\begin{aligned}
& \mathrm{B}_{1}-\text { svetlosni signal od objekta; } \\
& \mathrm{B}_{2}-\text { svetlosni signal od okoline } \mathrm{i} \\
& \mathrm{C}-\text { kontrast. }
\end{aligned}
$$

Kako je svetlost po svojoj prirodi podložna slučajnim fluktuacijama intenziteta, to se i kontrast može smatrati statističkom veličinom ( $\mathrm{tj}$. pojavljuje se sa odgovarajućom verovatnoćom tokom vizuelnog procesa). Kontrast u sceni je osnovni nosilac informacije o objektima u sceni. Kontrast slike koju registruje oko zavisi od prenosnih funkcija svih uticajnih faktora koji učestvuju u formiranju slike pri upotrebi pasivnih sprava. Smatra se da, pri normalnim (dnevnim) uslovima osvetljaja, minimalna vrednost kontrasta $u$ slici koju oko može razlikovati iznosi 0,02 (ili $2 \%$ ).

Elementi optičkog sistema optoèlektronskih sprava optimiziraju se za najpovoljnije uslove prenosa kontrasta, tj. njihove prenosne funkcije moraju biti takve da unose minimalne promene u kontrast koji postoji u posmatranoj sceni.

\section{Uticaj izvora zračenja}

Uticaj izvora svetlosti tokom vizuelnog procesa pri upotrebi optoelektronskih uređaja je višestruk i izražen je kroz:

- osvetljenost objekata u sceni (intenzitet i spektralne karakteristike izvora);

- kontrast objekata u sceni (prostorni raspored luminancije koji zavisi od karakteristika korišćenih izvora, oblika i refleksionih karakteristika objekata $\mathrm{u}$ pravcu ose optoelektronskog uređaja);

- rasejanje zračenja u atmosferi na putu prostiranja zračenja (aditivni izvor zračenja na trasi koji utiče na smanjenje kontrasta u sceni pri prijemu i konverziji slike).

Ovi uticaji opredeljuju izbor karakteristika prijemnika i optimizaciju podsklopova optoelektronske sprave.

Izvori zračenja mogu se podeliti na prirodne (koriste se za rad pasivnih sprava) i veštačke (koriste se u aktivnim spravama).

Prirodni izvori zračenja su Sunce, Mesec, zvezde i zračenje noćnog neba. Zraćenje Sunca se praktično ne koristi u pasivnim uređajima izuzev u sumraku ili zori ili kao reflektovano zračenje 


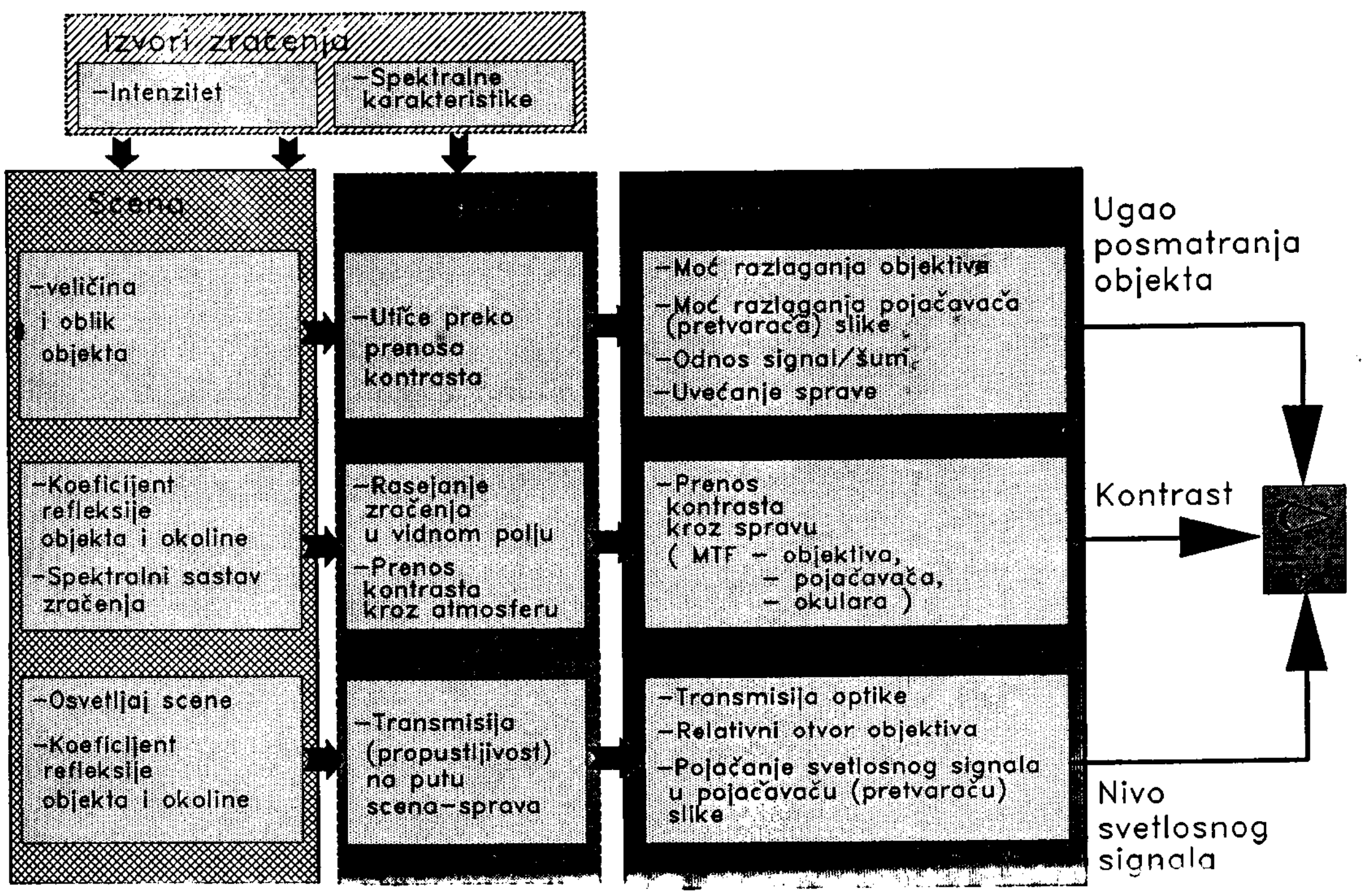

Sl. 3 Sematski prikaz delovanja uticajnih faktora na funkcionisanje pasivnih sprava

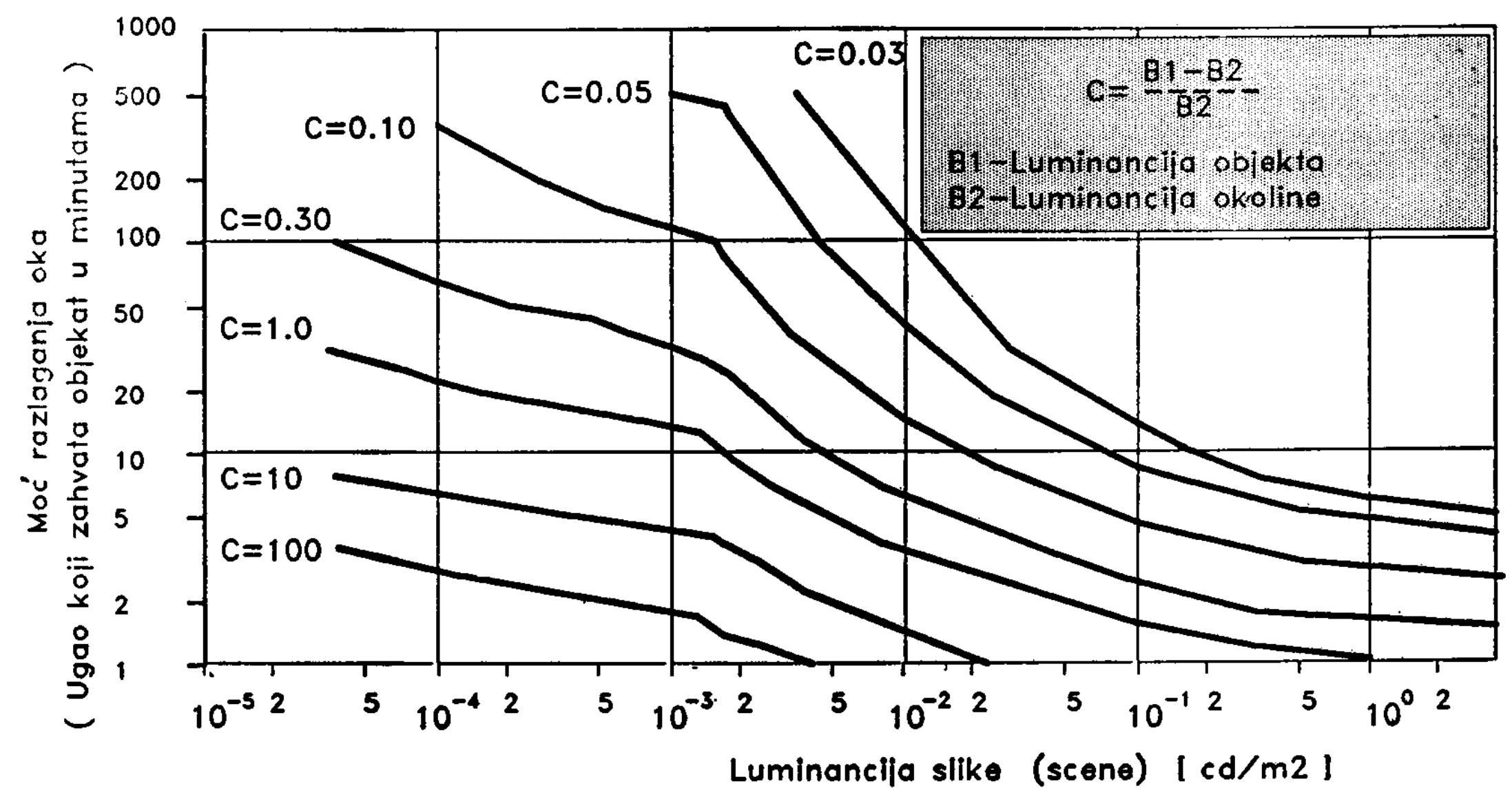

Sl. 4 Zavisnost moći razlaganja (ugla pod ko jim se vidi neki objekat ili njegov detalj) u funkciji kontrasta $i$ luminacije posmatrane slike 
Meseca. Tipične spektralne raspodele intenziteta zračenja Meseca i zvezda prikazane su na slici $5[1,2,6]$. Osvetljenost objekata u sceni jako zavisi od doba dana ili noći i geometrijskog položaja izvora $u$ odnosu na scenu. U tabeli 1 [3] prikazana je zavisnost osvetljenosti na površini zemlje za različite faze meseca (elongacije-ugaone udaljenosti od Sunca) i ugaone visine . lad horizontom.

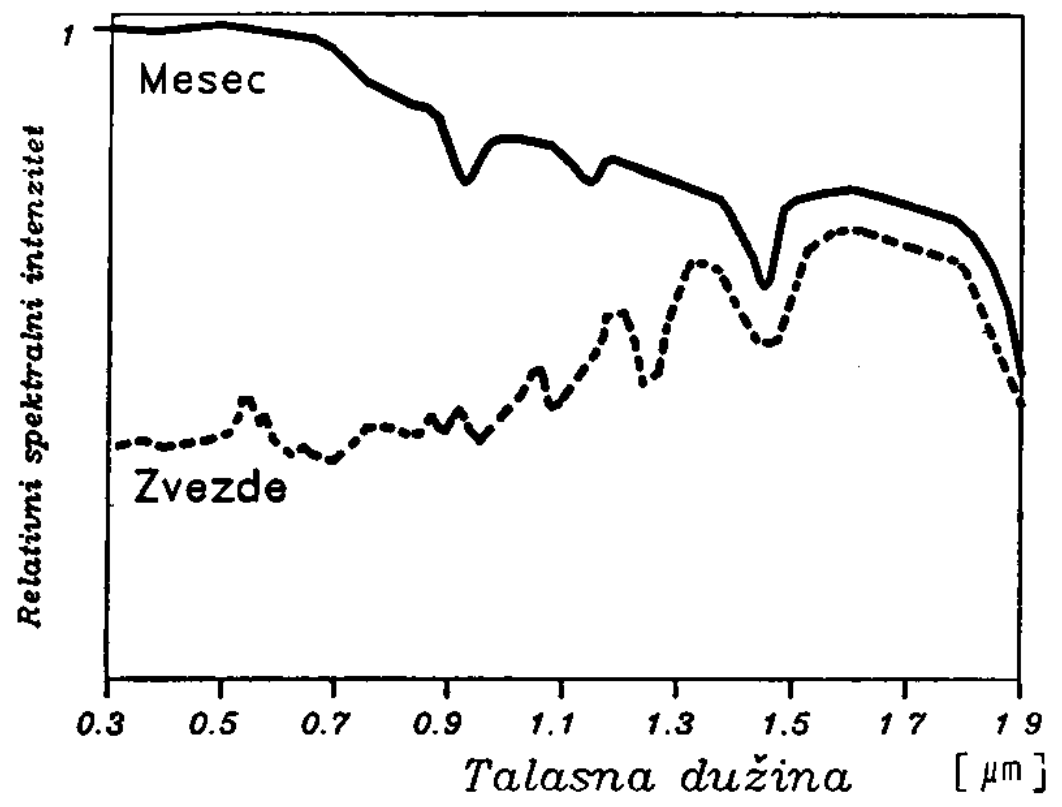

Sl. 5 Relativna spektralna raspodela intenziteta zračenja Meseca $i$ zvezda
U tabeli 2 [3] prikazan je orijentacioni nivo osvetljenosti površine zemlje za različite uslove (meteorološki uslovi ili doba dana). Kako se nebeski svod, u praktičnim primenama, često pojavljuje kao pozadina ili kao izvor zračenja u noćima bez meseca i zvezda, korisno je poznavati karakteristike zračenja nebeskog svoda. U tabeli 3 [3] prikazani su nivoi lumunancije neba $u$ blizini horizonta pri različitim uslovima.

Veštački izvori zračenja koriste se u aktivnim IC uređajima [5]. U ovim izvorima zračenja najčešće se koriste lampe sa usijanim volframskim vlaknom (sijalice, halogene lampe) ili ksenonske lampe visokog pritiska sa kratkim lukom, uz obaveznu primenu IC filtra koji prigušuje vidljivo zračenje (maskiranje izvora za golo oko). Takođe se koriste i poluprovodnički laseri (GaAs, GaAlAs-impulsni ili kontinualni) $u$ nekim uređajima specijalne namene.

Tabela 1

Osvetljenost horizontalne površine pri različitim fazama meseca

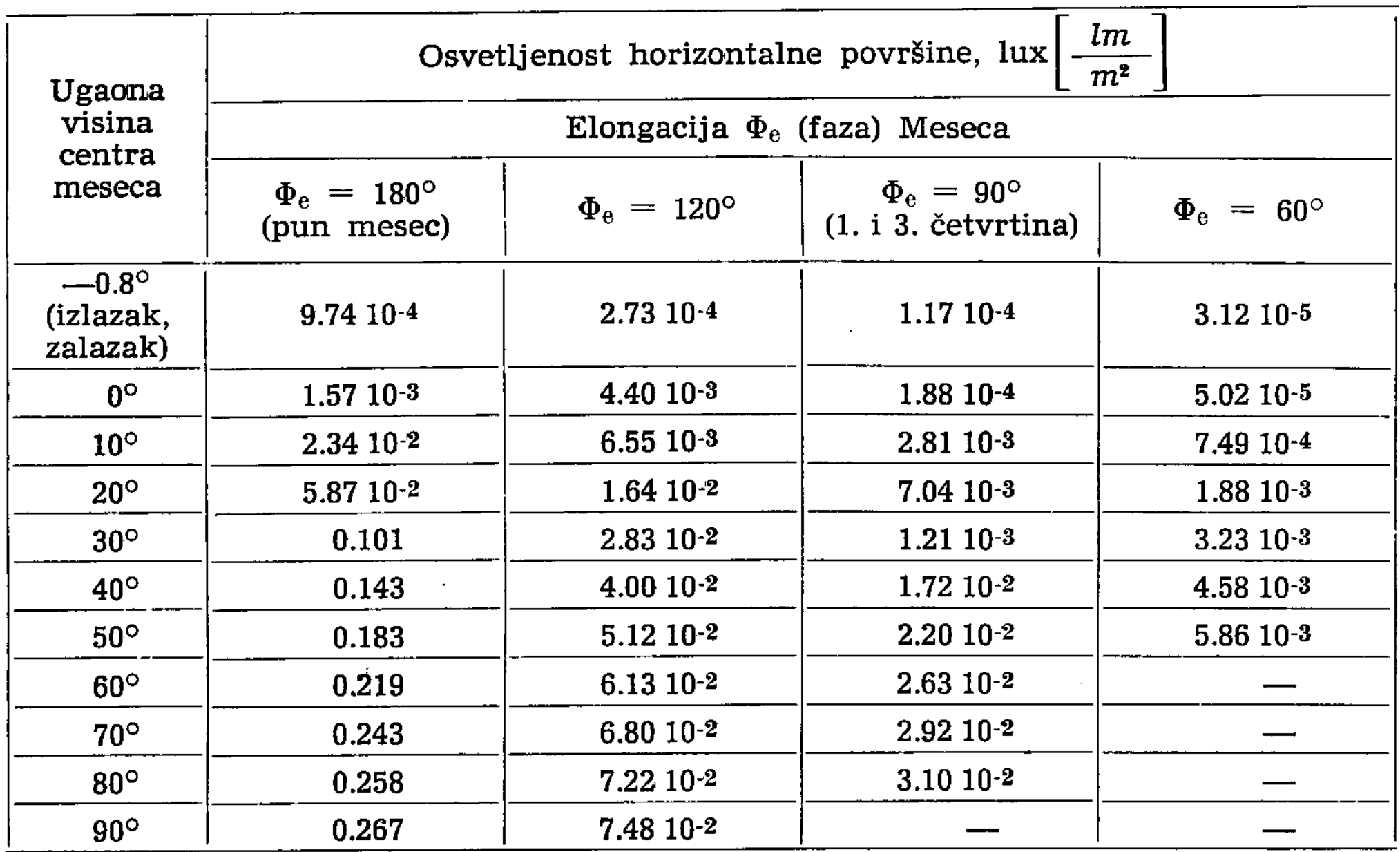


Tabela 2

Približni nivoi osvetljenosti pri različitim uslovima osvetljavanja scene prirodnim izvorima zračenja

\begin{tabular}{|l|c|}
\hline \multicolumn{1}{|c|}{$\begin{array}{c}\text { Karakteristike stanja } \\
\text { neba }\end{array}$} & $\begin{array}{c}\text { Nivo osvet- } \\
\text { ljenosti } \\
\text { lux }\left[\frac{\mathrm{lm}}{\mathrm{m}^{2}}\right]\end{array}$ \\
\hline Direktno zračenje Sunca & $1-1.310^{5}$ \\
\hline Sunčan dan & $1-210^{4}$ \\
\hline Oblačno & $10^{3}$ \\
\hline Vrlo tmuran dan & $10^{2}$ \\
\hline Sumrak & 10 \\
\hline \begin{tabular}{l} 
Duboki sumrak \\
\hline Pun mesec
\end{tabular} & 1 \\
\hline $\begin{array}{l}\text { Cetvrtina meseca } \\
\text { Bez meseca, vedro noć- } \\
\text { no nebo }\end{array}$ & $10^{-1}$ \\
\hline Bez meseca, oblačno & $10^{-2}$ \\
\hline
\end{tabular}

Tabela 3

Približni nivoi luminacije neba $u$ visini horizonta pri različtim uslovima

\begin{tabular}{|l|c|}
\hline $\begin{array}{c}\text { Karakteristike stanja } \\
\text { neba }\end{array}$ & $\begin{array}{c}\text { Nivo lumi- } \\
\text { nacije neba } \\
{\left[\frac{\mathrm{cd}}{\mathrm{m}^{2}}\right]}\end{array}$ \\
\hline Vedar dan & $10^{4}$ \\
\hline $\begin{array}{l}\text { Oblačan dan } \\
\text { Jako oblačan dan }\end{array}$ & $10^{3}$ \\
\hline $\begin{array}{l}\text { Zalazak Sunca, oblačan } \\
\text { dan }\end{array}$ & $10^{2}$ \\
\hline $\begin{array}{l}1 / 4 \text { sata po zalasku Sun- } \\
\text { ca, vedro }\end{array}$ & 10 \\
\hline $\begin{array}{l}\text { 1/2 sata po zalasku Sun- } \\
\text { ca, vedro }\end{array}$ & $10^{-1}$ \\
\hline \begin{tabular}{l} 
Jako svetao mesec \\
\hline $\begin{array}{l}\text { Bez mesečine, vedro no- } \\
\text { ćno nebo }\end{array}$
\end{tabular} & $10^{-2}$ \\
\hline $\begin{array}{l}\text { Bez meseca, oblačno no- } \\
\text { ćno nebo }\end{array}$ & $10^{-3}$ \\
\hline
\end{tabular}

Na slici $6[1,2,6]$ prikazane su spektralne zavisnosti koeficijenta refleksije nekih prirodnih materijala koji doprinose formiranju kontrasta u sceni.

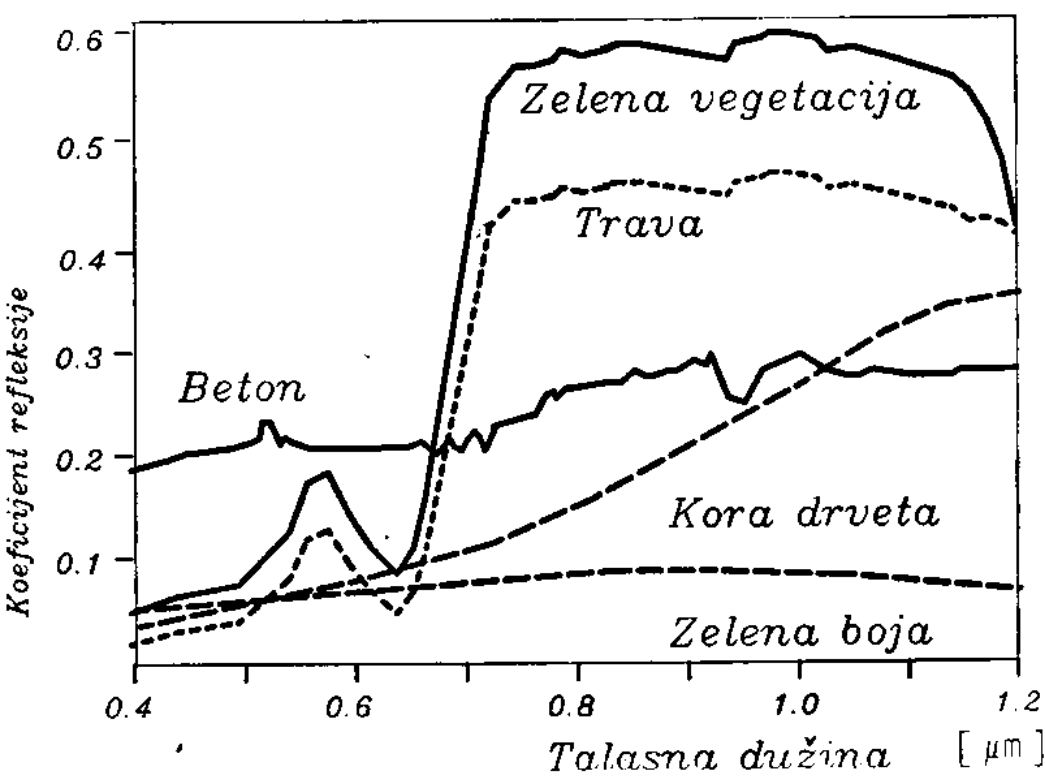

Sl. 6 Spektralna zavisnost koeficijenta refleksije nekih prirodnih materijala

\section{Uticaj atmosfere}

Pri upotrebi optoelektronskih sprava (pasivnih i aktivnih) atmosfera deluje kompleksno, pri čemu su najznačajniji uticaji procesa koji mogu znatno degradirati karakteristike sprava:

- slabljenje energije zračenja koje nosi informaciju o sceni (proces apsorpcije na molekulima i atomima; proces rasejanja na submikronskim česticama - Rejlijevo rasejanje, rasejanje na česticama aerosola - Mieovo rasejanje);

- rasejanje zračenja prirodnih i veštačkih izvora na putu duž optičke ose uređaja koje se pojavljuje kao dodatni aditivni ịzvor zračenja koji utiče na smanjenje kontrasta scene pri prijemu;

- turbulencije i slučajne nehomogenosti optičkih karakteristika atmosfere na trasi prenosa kontrasta koje doprinose pojavi šuma i time uzrokuju smanjenje kontrasta.

Slabljenje energije zračenja jako zavisi od atmosferskih uslova, a pre svega od količine i stanja vodene pare i vode $u$ atmosferi i utiče na domet optoelektronskih uređaja. Stanje slabljenja u atmosferi izražava se preko koe- 
ficijenta slabljenja, a često se koristi i pojam »meteorološka vidljivost k koji izražava udaljenost na kojoj se, u normalnim dnevnim uslovima, mogu uočiti objekti po zadatom kriterijumu. Slika $7[3,5,8]$ ilustruje međusobnu vezu meteorološke vidljivosti $\left(R_{v}\right)$ i koeficijenta slabljenja $(\sigma)$ za različite meteorološke uslove u atmosferi. Meteorološka vidljivost i koeficijent slabljenja vezani su preko relacije:

$$
\mathrm{R}_{\mathrm{v}}=\frac{3.912}{\sigma}
$$

koja je izvedena na osnovu minimalne vrednosti kontrasta koju oko razlikuje $(2 \%)$. Koeficijent transmisije atmosfere ( $\tau)$ duž puta dužine 1 je:

$$
\tau=\exp (-\sigma \cdot 1)
$$

Stanje meteoroloških uslova u atmosferi na domet pasivnih sprava utiče slično kao i kod optičkih uređaja i teško se može jednoznačno okarakterisati. Za procenu uticaja atmosfere koriste se prosečne vrednosti meteorološke vidljivosti za različite geografske regione u funkciji doba godine i dana i kvalitativnog opisa meteoroloških uslova. Izmerene vrednosti meteorološke vidljivosti pri konkretnim uslovima primene daju dobru osnovu i za procenu dometa pasivnih sprava u tim uslovima. Praksa pokazuje da je, pri vrednostima meteorološke vidljivosti manjim od $10 \mathrm{~km}$, vidljiv uticaj stanja atmosfere pri upotrebi pasivnih sprava.

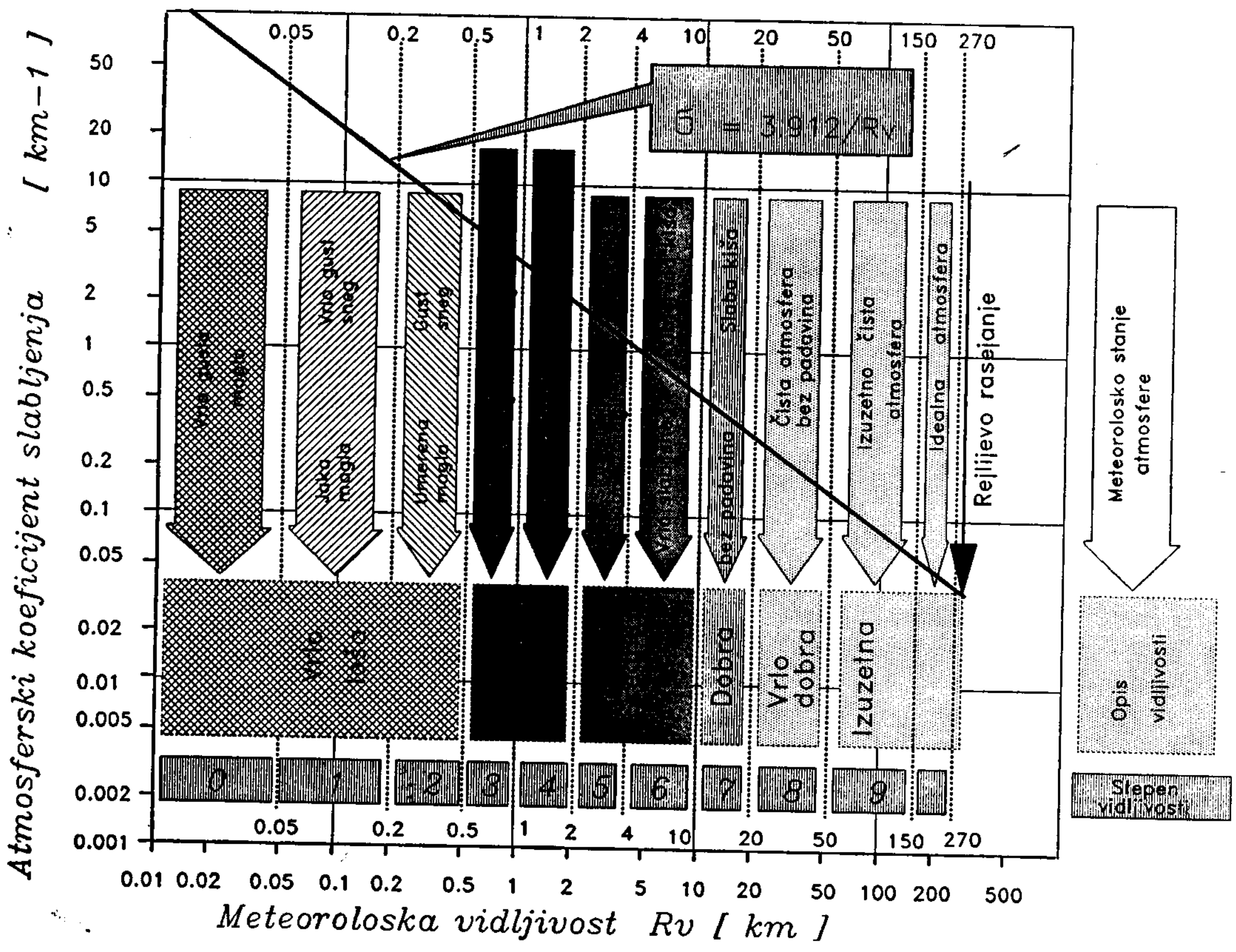

Sl. 7 Meteorološka vidljivost, atmosferski ko eficijent stanja atmosfere 
Konstrukcija i karakteristike pojačavača slike

Pretvarači i pojačavači slike su specijalne vakuumske elektronske cevi, koje se sastoje od sledećih osnovnih komponenti:

- fotokatoda čiji je osnovni element sloj fotoosetljivog materijala na kome se pomoću objektiva formira lik posmatrane scene a koji na osnovu fotoelektričnog efekta vrši transformaciju lika u elektronsku sliku (površinska raspodela fotogenerisanih elektrona je srazmerno površinskoj raspodeli osvetljenosti fotokatode). Spektralne zavisnosti strujne osetljivosti najčešće korišćenih fotokatoda prikazane su na slici $8[3,4]$, a moć razlaganja fotokatoda pojačavača slike na slici 9 [7];

- pojačavački sistem u kome se vrši pojačanje i prenos elektronske slike na elektroluminescentni ekran, pomoću umnožavanja i povećanja energije elektrona, a uz minimalne deformacije površinske gustine fotogenerisanih elektrona. Umnožavanje i povećanje energije elektrona najčešće se vrši primenom visokog napona, a preslikavanje na elektroluminescentni ekran korišćenjem elektrostatičkih ili elektromagnetskih sočiva (otklonskih sistema);

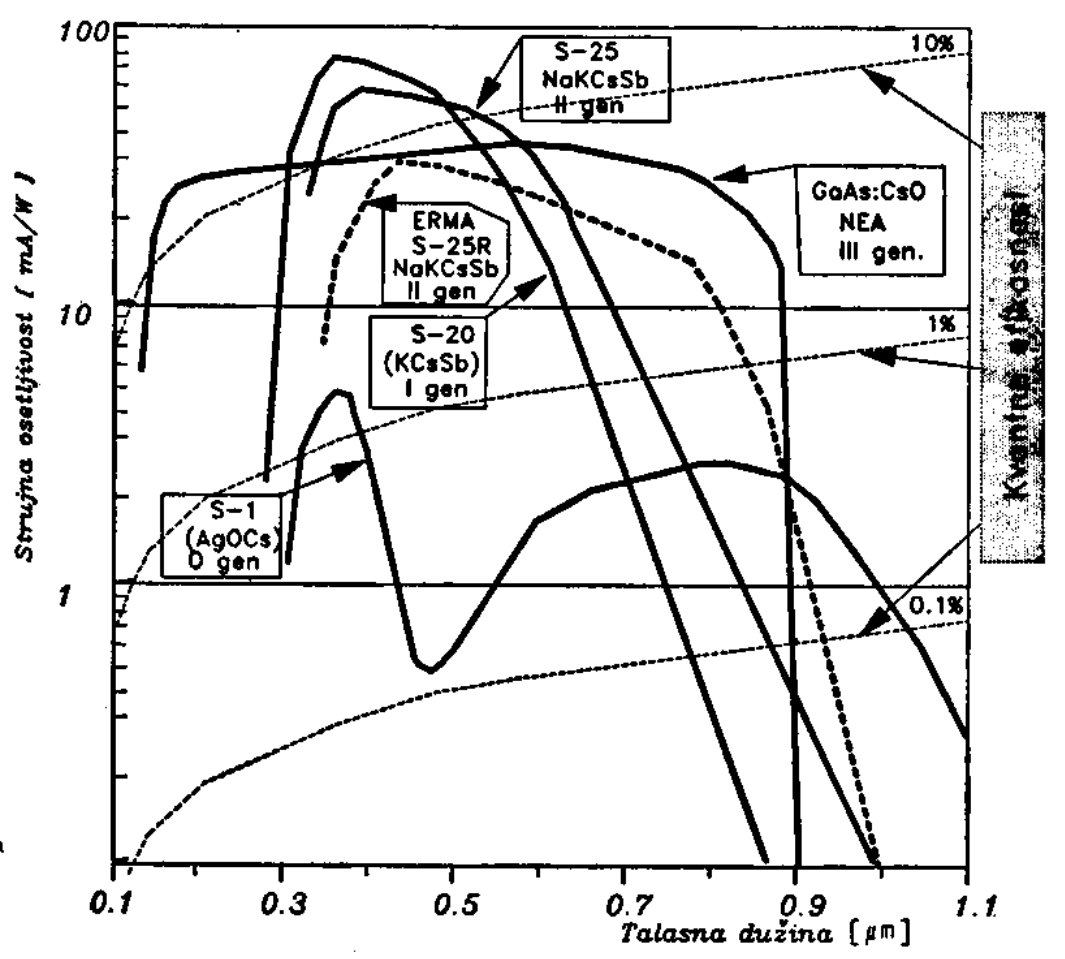

Sl. 8 Spektralne zavisnosti strujne osetljivosti najčešće korišćenih tipova fotokatoda $u$ pojačivačima slike
- elektroluminescentni ekran omogućava vizualizaciju elektronske slike, tako što generiše vidljivu sliku čija je luminancija srazmerna broju upadnih elektrona, a kontrast odgovara površinskoj gustini elektrona $\mathrm{u}$ prenetoj elektronskoj slici.

U pojačavačima slike poseban značaj ima primena komponenti od stopljenih staklenih vlakana (ploče, sočiva, obrtači slike), čijom se strukturom i načinom formiranja može doprineti poboljšanju kvaliteta cevi u celini.

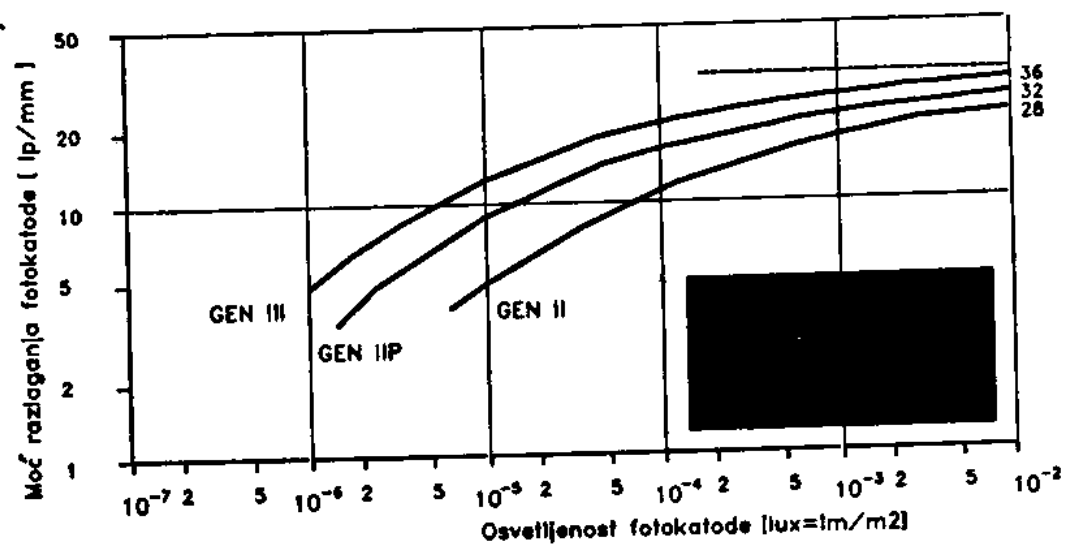

Sl. 9 Zavisnost moći razlaganja od nivoa osvetljenosti fotokatode za različite generacije pojačavača slike

U zavisnosti od vrste fotokatode i pojačavačkog sistema, razlikuje se više generacija pojačavača slike:

»0« generacija (pretvarači slike). Struktura pretvarača slike slična je kao kod jednostepenih pojačavača slike I generacije (prvi stepen na slici 10). Primenjena je fotokatoda tipa S-1 (srebro-oksid cezijumska) koja je osetljiva u vidljivom i bliskom infracrvenom delu spektra. Pojačanje se vrši u jakom električnom polju (radni napon 12 do $18 \mathrm{kV}$ ) a elektrostatička sočiva obrću sliku. Elektroluninescentni ekran je od cink-sulfida (tip P-20) sa srednjom inercijom. Zbog male osetljivosti (kvantne efikasnosti) fotokatode, pretvarači slike se koriste $\mathrm{u}$ aktivnim uređajima. Osetljivost fotokatode u IC delu spektra omogućava primenu filtriranja izvora zračenja, tako da je izvor nevidljiv za golo oko. Primena veštačkih izvora demaskira upotrebu uređaja $\mathrm{i}$ to je osnovni nedostatak aktivnih uređaja. Kod 
aktivnih uređaja proces rasejanja zračenja u atmosferi može znatno degradirati ukupne karakteristike. Pretvarač visokog napona se napaja iz akumulatora $(6-24 \mathrm{~V})$ i nije integrisan u sklop cevi.

I generacija. Usavršavanjem materijala za fotokatode i primenom multialkalnih fotokatoda (S-20, S-20R, S-25) omogućena je dovoljna osetljivost za primenu pojačavača slike $u$ pasivnom režimu. Uz primenu elemenata od stopljenih optičkih vlakana omogućeno je optički efikasno međusobno spajanje više pojačavačkih cevi u jedan sklop, a time i realizacija višestepenih pojačavača slike I generacije (sl. 10). U višestepenim pojačavačima slike prvi stepen mora imati najveće pojačanje, dok ostali stepeni moraju imati dobre optičke karakteristike. Broj ugrađenih komponenti $u$ višestepeni pojačavač zavisi od namene i određuje domet uređaja. Pojačavači slike I generacije se prave $u$ dve verzije $u$ odnosu na prečnik osetljive površine fotokatode: 18 i 25 $\mathrm{mm}$. Napon napajanja cevi je visok (12$15 \mathrm{kV}$ po stepenu). Pretvarači visokog napona mogu se napajati iz baterija na- pona 2,5 do $6,5 \mathrm{~V}$, a visoki napon se generiše pomoću minijaturnih poluprovodničkih pretvarača napona (diodno-kondenzatorske lestvičaste mreže). Konstrukciono su izvedeni tako da obuhvataju cev i smeštaju se u zajedničko kućište. Pretvarači visokog napona omogućavaju delimičnu automatsku regulaciju luminancije ekrana preko regulacije pojačanja cevi, što omogućava primenu pasivnih sprava i pri promenljivom i višem nivou osvetljaja scene.

II generacija. Primena tehnike umnožavanja elektrona $u$ uskom staklenom kanalu prečnika 10-12 $\mu \mathrm{m}$, koji na zidovima ima otporni sloj kao izvor sekundarnih elektrona (sl. 11) i odgovarajućih tehnoloških rešenja (stapanje optičkih vlakana) omogućili su formiranje pločice sa velikim brojem kanala (mikrokanalna pločica-MKP), debljine oko $0,5 \mathrm{~mm}$, koja uz primenu visokog napona reda $1 \mathrm{kV}$ omogućuje zadovoljavajući nivo strujnog pojačanja. Primenom MKP u pojačavačima znatno se uprošćava konstrukcija (sl. 12) i doprinosi poboljšanju karakteristika: smanjenje gabarita i veću otpornost na smetnje. Pri pojavi tačkastog snažnog

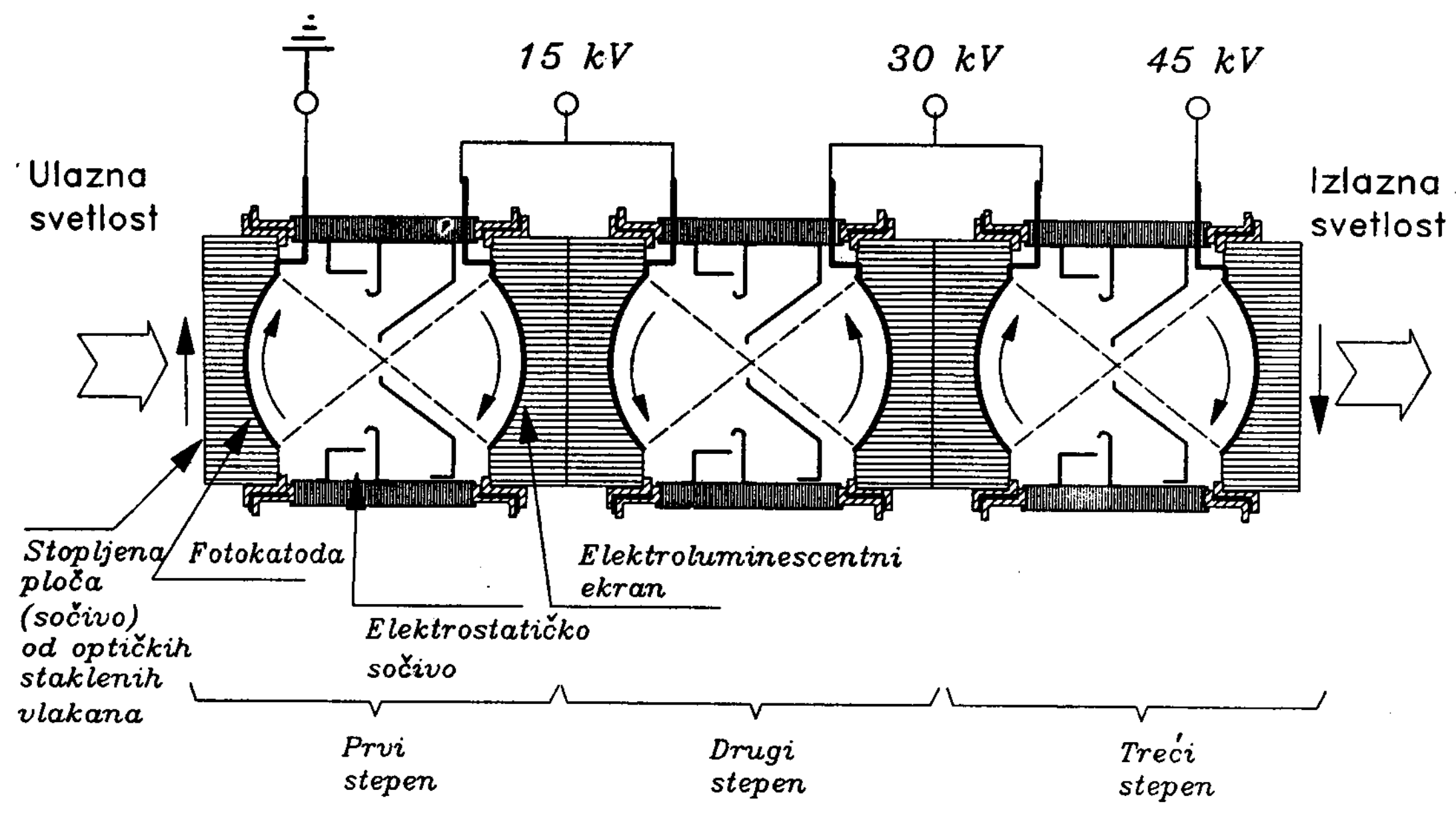

Sl. 10 Trostepeni pojačavač slike I generacije 
izvora svetlosti $u$ vidnom polju sprave I generacije dolazi do gubitka slike na celoj površini ekrana (zasićenje cevi), dok je kod sprava II generacije zasićenje ograničeno na samo nekoliko kanala, odnosno na samo malom delu ekrana.

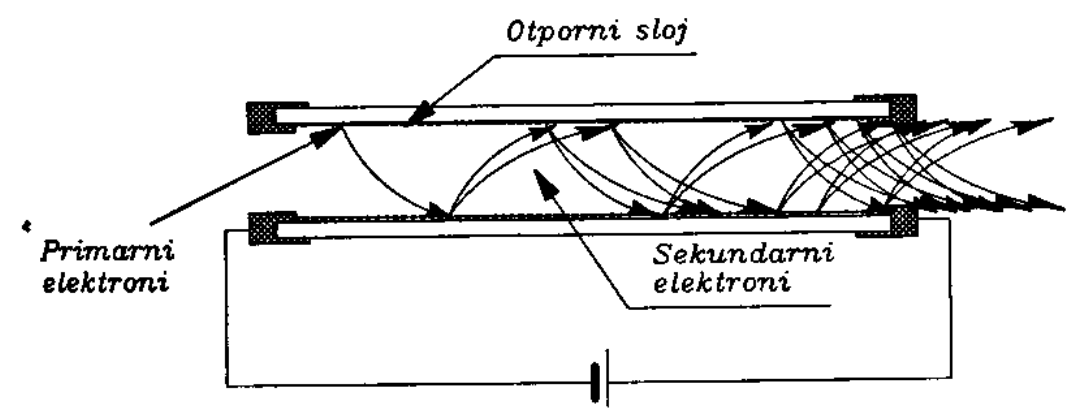

Sl. 11 Umnožavanje elektrona u kanalu mikrokanalne pločice pona za cev pretvarač napona omogućava i druge funkcije: regulaciju nivoa luminancije ekrana (nezavisnost svetljenja od osvetljenosti fotokatode); stabilizaciju napona napajanja cevi za široki opseg napona baterije $2-3 \mathrm{~V}$ ) i radnih temperatura kao i regulaciju svetlosnog pojačanja cevi. Fotokatoda je multialkalna (S-25, S-25R).

III generacija. Uvođenjem fotokatode sa negativnim izlaznim radom (NEA) na bazi GaAs, koja ima znatno povišenu osetljivost posebno $u$ bliskom IC delu spektra, omogućeno je dalje usavršavanje i minijaturizacija pojačavača slike. Kod pojačavača slike III ge-

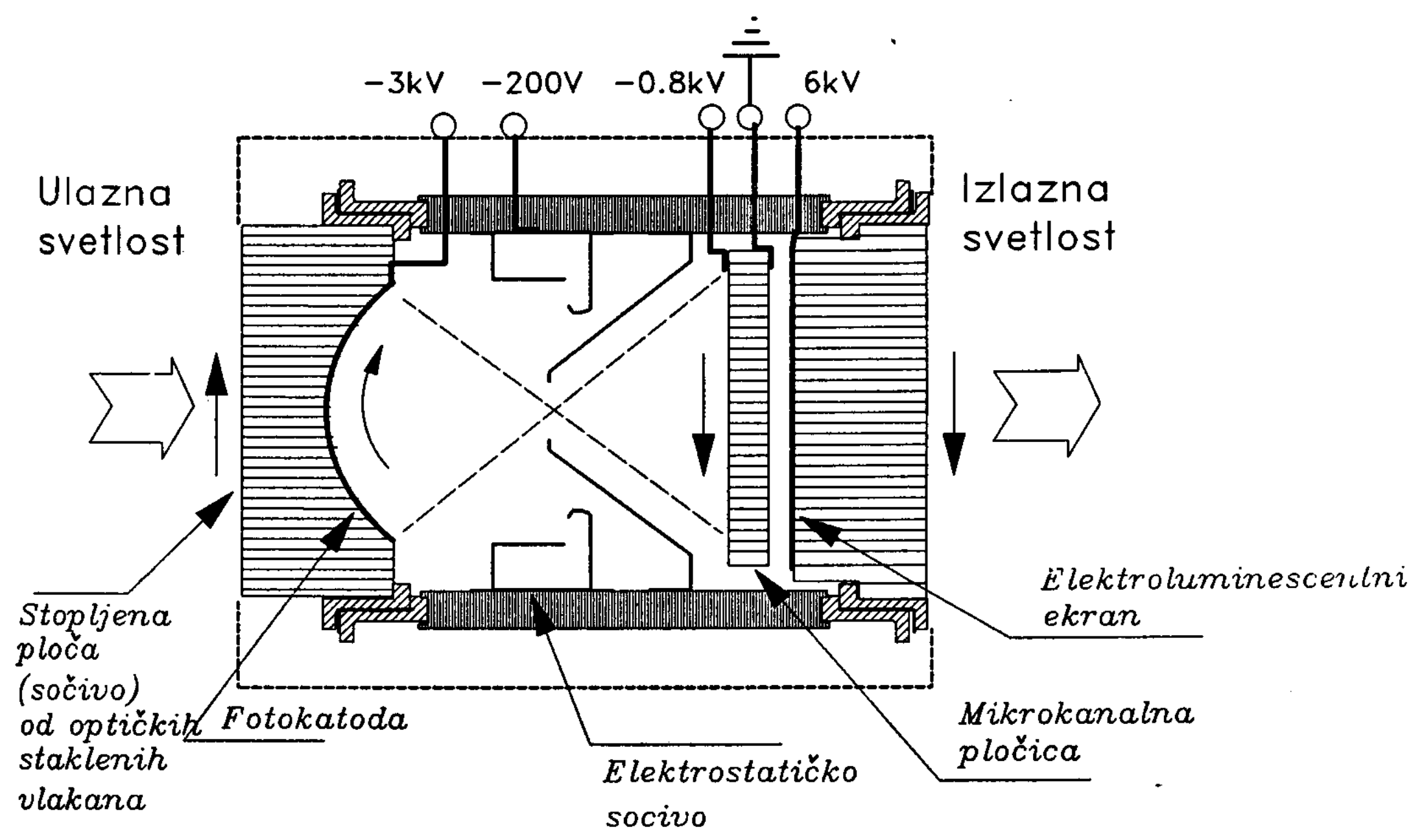

Sl. 12 Pojačavač slike sa mikrokanalnim umnoživačem elektrona (II generacija sa obrtanjem slike)

Pojačavači slike II generacije proizvode se u dve osnovne varijante: 25 mm sa obrtanjem slike (sl. 12) i $18 \mathrm{~mm}$ sa blizinskim fokusiranjem (sl. 13). Radni naponi su mnogo niži nego kod I generacije (vidi sl. 12). Pretvarač napona je minijaturni poluprovodnički sklop smešten oko cevi u zajedničkom kućištu. Pored obezbeđenja radnih na- neracije koristi se struktura sa blizinskim fokusiranjem (sl. 13) sa prečnikom fotokatode $18 \mathrm{~mm}$. Zaštita fotokatode od erozije jonima prisutnim na MKP realizuje se nanošenjem tankog sloja $\mathrm{Al}_{2} \mathrm{O}_{3}$, koji propušta elektrone, ali ne i jone, na MKP. Zbog savlađivanja te barijere napon između fotokatode i MKP je povećan sa $200 \mathrm{~V}$ (II gen.) na 
800 V. Napon na MKP je oko $1 \mathrm{kV}$, a između MKP i ekrana je $6 \mathrm{kV}$, što je isto kao i kod cevi druge generacije sa blizinskim fokusiranjem.
* U okviru složenih sistema pasivne sprave se najčešće ugrađuju u: borbena vozila (sprava komandira, nišanska sprava, podsklop SUV-a, pasivni pe-

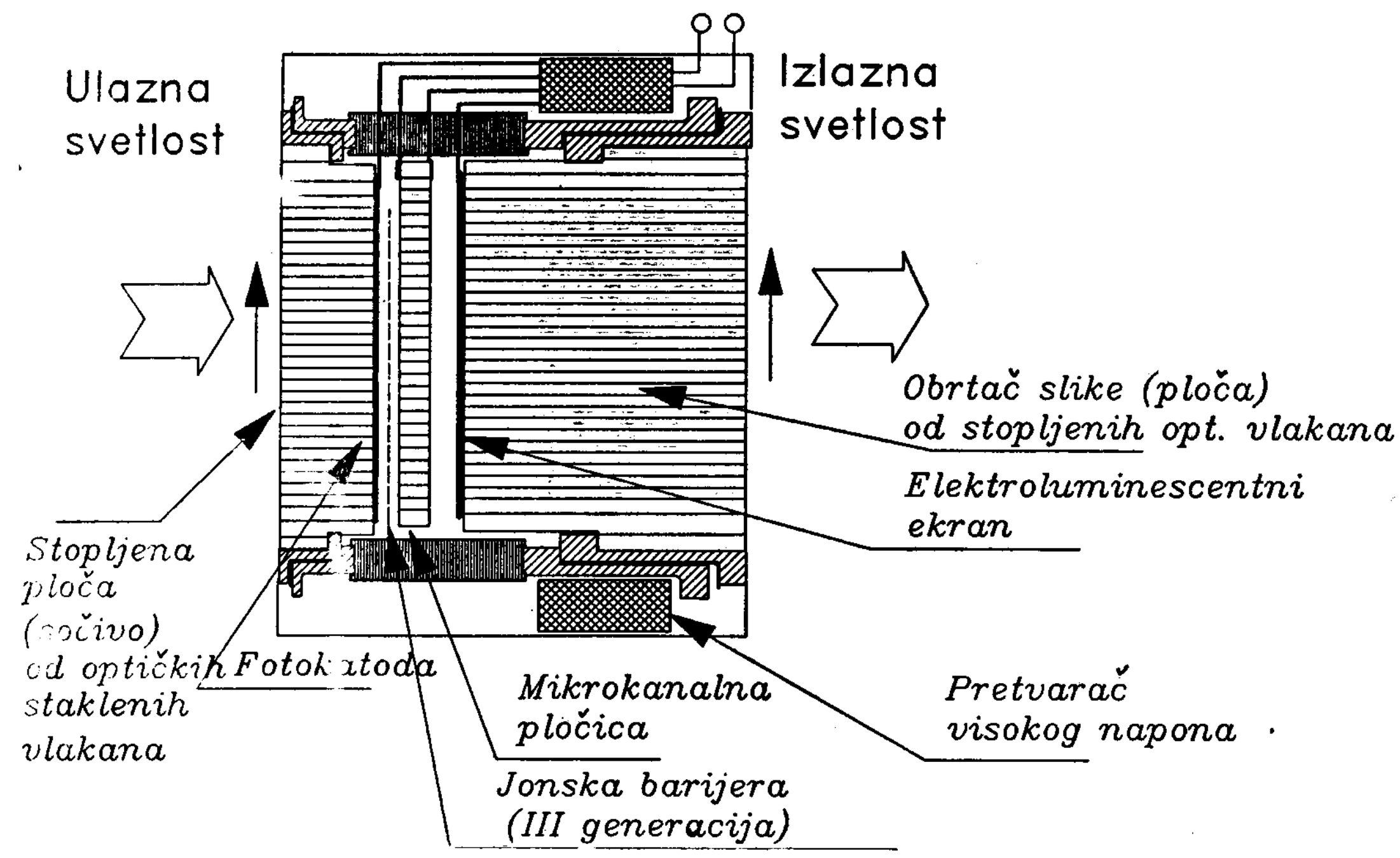

Sl. 13 Pojačavač slike sa blizinskim fokusiranjem (II ili III generacija)

\section{Vojne primene pasivnih sprava sa pojačavačima slike}

Pasivni uređaji sa pojačavačima slike imaju vrlo široku primenu u vojnim sistemima za omogućavanje vizuelnog kontakta sa protivnikom i prostorom $\mathrm{u}$ kome se izvode borbena dejstva [8-14]. Primene su različite pri čemu se najčešće sreću, bilo kao individualni komplet (uz vojnika ili oruđe), bilo kao podsklop složenih sistema.

* Pasivne sprave uz vojnika ili oruđe (individualni komplet) koriste se za: osmatranje i izviđanje (pasivni dvogled, pasivna sprava za osmatranje), nišanjenje (pasivni noćni nišani pešadijskog i artiljerijskog naoružanja), noćnu vožnju (pasivni periskopi i naočare za noćnu vožnju). riskop vozača); artiljerijska sredstva (SUV topa, pasivni noćni nišan u sistemu vođenih raketa); sistemi PVO (noćna nišanska sprava u okviru SUV PA topova ili prenosnih sistema samonavođenja raketa), vazduhoplovstvo (pasivne naočare za noćno pilotiranje helikoptera).

Namena i način ugradnje pasivnih sprava $u$ sistem opredeljuje konstrukciju i izbor komponenti sprave. Najčešće konstrukcije pasivnih sprava prikazane su na slici 14. Mnoge primene zahtevaju da se prave kombinovane dnevno-noćne sprave, pri čemu konstrukciona rešenja mogu biti znatno složenija od osnovnih varijanti prikazanih na sl. 14. 


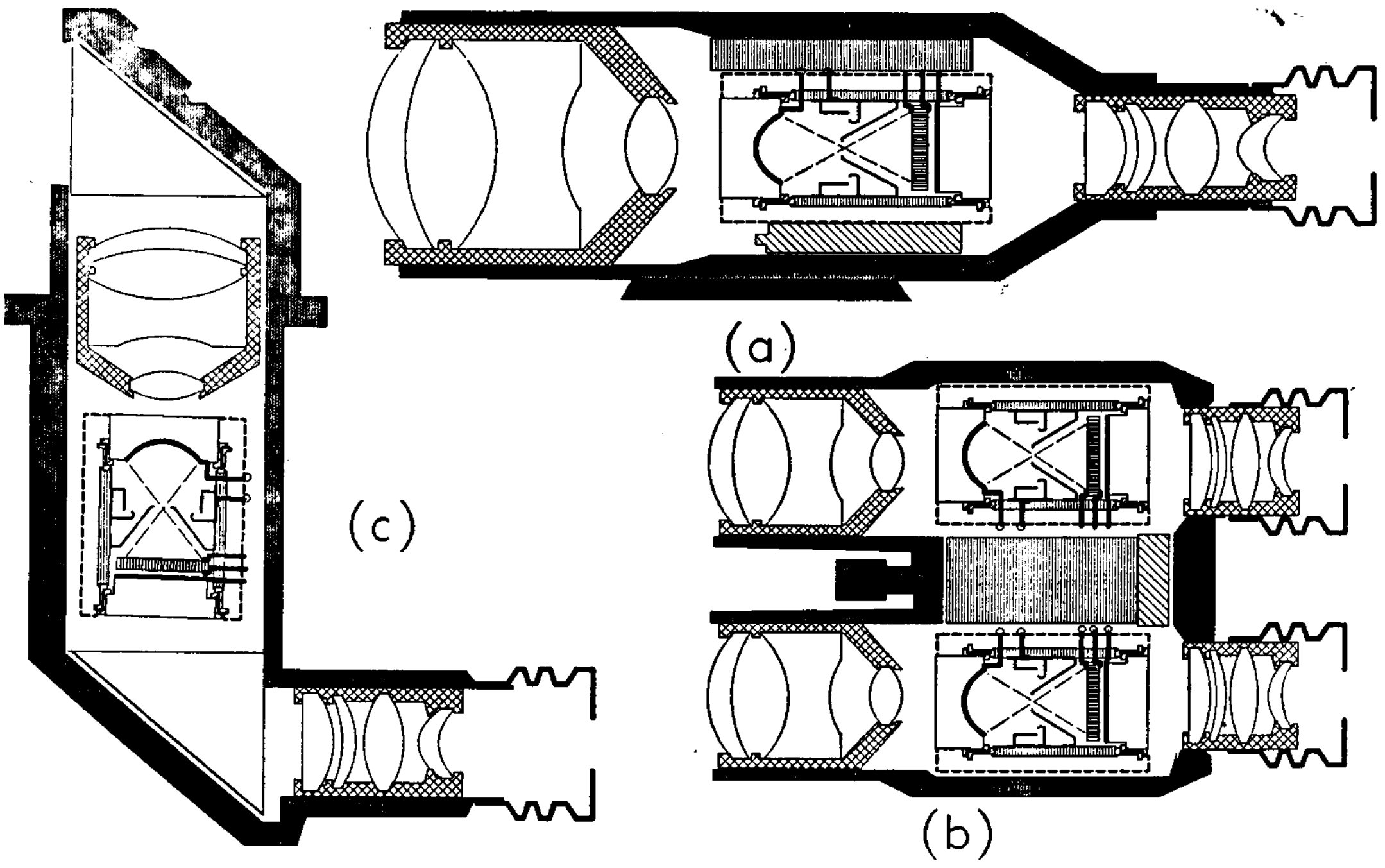

Sl. 14 Primeri najčešćih primena pojačavača slike u vojnim optoelektronskim spravama

(a) teleskop (noćni nišan, uređaji za osmatranje)

(b) dvogled (pasivni noćni dvogled, naočare za noćnu vožnju)

(c) periskopi (periskop za noćnu vožnju, komandirska sprava, nišanske sprave)

\section{Specifičnosti upotrebe pasivnih sprava}

Pojačanje rezidualne svetlosti osnovni je proces koji omogućava upotrebu pasivnih sprava za realizaciju vizuelnog kontakta sa okolinom i u atežanim uslovima vidljivosti, i svi faktori koji utiču na nivo osvetljenosti i proces transformacije slike utiču na efikasnost primene pasivnih sprava, a najznačajniji su:

* Meteorološki uslovi. Kako stanje i količina vlage $u$ atmosferi bitno doprinosi slabljenju zračenja u atmosferi, to se, u uslovima kada postoji sumaglica, magla, kiša ili sneg, bitno umanjuju mogućnosti pasivnih sprava. Posebno je kritičan uticaj sumaglice i magle, i to više kod aktivnih nego kod pasivnih uređaja. Kiša deluje različito: ukoliko je kiša sitna i gusta tada su pasivne sprave praktično neupotreblji- ve; ako su kapi kiše krupne i retke tada su uslovi za primenu pasivnih sprava povoljni.

* Konstrukcione karakteristike. Ukupni gabariti, mesto ugradnje i vidno polje pasivne sprave ograničavaju mogućnosti upotrebe i stoga konstrukcija mora biti prilagođena nameni.

* Karakteristike slike. Slika na elektroluminescentnom ekranu pasivnih sprava je najčešće zelene boje, a kontrast je izražen kroz nivo luminacije ekrana (nivo sivog). Iako kontrast slike koja se dobija primenom pasivnih sprava daje dovoljno elemenata prostornosti, ipak u potpunosti ne odgovara vidljivoj slici na koju smo naviknuti. Pored toga, i zrnasta struktura slike uz treperenje i bliskanje (slično $»$ snegu $\ll u$ TV slici) zahteva dodatnu obuku vojnika (operatora) radi navikavanja na sliku i uvežbavanja u uočavanju detalja slike. 
* Nivo osvetljenosti. Pasivne sprave su upotrebljive $i \mathrm{u}$ uslovima potpunog mraka (bez Meseca i zvezda) uz korišćenje zračenja vedrog noćnog neba. Svojstva pojačavača slike novijih generacija (II i III) omogućavaju primenu pasivnih sprava i pri višem nivou osvetljaja (sumrak, zora) kada se objekti uočavaju i golim okom, ali primenom pasivnih sprava znatno se povećava domet i rezolucija pri osmatranju, pa se preporučuje primena pasivnih sprava $u$ ovim uslovima. Međutim, pri dugotrajnom izlaganju fotokatode pojačavača slike visokom nivou osvetljenosti, dolazi do trajne degradacije karakteristika fotokatode. Pojava degradacije karakteristika (do uništenja) fotokatode izraženija je pri uključenom napajanju, ali postoji i pri isključenom napajanju, pa se u dnevnim uslovima mora obezbediti zaštita katode pojačavačke cevi.

Iako su konstrukcija i primena pasivnih sprava sa pojačavačima slike relativno jednostavni, za povećanje efikasnosti i pouzdanosti njihove primene neophodna je i posebna obučenost vojnika (operatora) za rukovanje i osnovno održavanje sprava.

Osnovna mera efikasnosti upotrebe je domet optoelektronskih sprava $\lceil 15$, 16], tj. maksimalna udaljenost objekta koji se može uočiti na zadatom nivou vizuelne percepcije (detekcija, prepoznavanje, identifikacija), uz primenu pasivnih sprava $\mathrm{u}$ zadatim uslovima. Domet pasivnih sprava je veličina koja zavisi od više faktora, ali najviše od konstrukcije sprave, vrste osmatranog objekta i meteoroloških uslova $u$ atmosferi. Kako ie meteorološke uslove u atmosferi i njihov uticaj teško jednoznačno opisati i kontrolisati, to je domet pasivnih sprava samo verovatna veličina (očekivana vrednost) koja služi samo kao orijentir pri proceni mogućnosti upotrebe. U zavisnosti od konstrukcije objektiva (ulazna aparatura, relativni otvor, uvećanje, moć razlaganja i drugih optičkih karakteristika) domet pasivnih sprava može biti u normalnim meteorološkim uslovima od 100 do 2000 $\mathrm{m}$. Orijentacione vrednosti prosečnih dometa pasivnih sprava za različite primene ilustrovane su na slici 15.

Mogućnosti izvođenja borbenih dejstava $\mathrm{u}$ otežanim uslovima vidljivosti zavise od pravilne upotrebe tehničkih sredstava (planiranje, opremanje, organizacija) za noćne uslove. Pored toga, na ukupnu efikasnost primene pasivnih sprava utiče i nivo poznavanja tehničkih sredstava, vezan za procenu uticaja meteoroloških uslova i osvetljenosti terena, kao i nivo obučenosti posada i tehničke ispravnosti sredstava. Pri procenama se koriste podaci o nivoima osvetljenosti i meteorološkim uslovima koji se obezbeđuju neprekidnim praćenjem ili preko prosečnih vrednosti dobijenih iz praćenja kroz duži vremenski period pojedinih značajnih parametara [17] (regionalni, dnevni, sezonski, godišnji).

Za naš geografski prostor karakteristično je nekoliko podataka vezanih za nivo osvetljenosti na godišnjem nivou: oko $50 \%$ ukupnog broja noćnih sati je sa mesečinom. Ako se uzme u obzir i oblačnost neba, tada, u zavisnosti od geografskog položaja, u oko 17 do $27 \%$ noćnih sati vladaju dobri uslovi za primenu pasivnih sprava; u oko 27 do $37 \%$ noćnih sati srednji uslovi; u oko 36 do $55 \%$ loši uslovi za primenu pasivnih sprava. Meteorološka vidlijivost takođe jako zavisi od geografskog položaja: dobra vidljivost $\left(\mathrm{R}_{\mathrm{V}}>10\right.$ $\mathrm{km})$ postoji u 56 do $97 \%$ noćnih sati; srednja i promenljiva vidljivost $(1 \mathrm{~km}<$ $\left.<\mathrm{R}_{\mathrm{V}}<10 \mathrm{~km}\right) 2$ do $40 \%$ noćnih sati; i loša vidljivost $\left(R_{V}<1 \mathrm{~km}\right)$ do $8 \%$ noćnih sati.

Izvođenjem napadnih borbenih dejstava u noćnim uslovima može se ostvariti: postizanje iznenađenja, održavanje i proširivanje postignutog uspeha, održavanje tempa napada, razbijanje jako utvrđenih tačaka protivnika, i dr.

Pri odbrambenim borbenim dejstvima noću, uz primenu pasivnih sprava, 


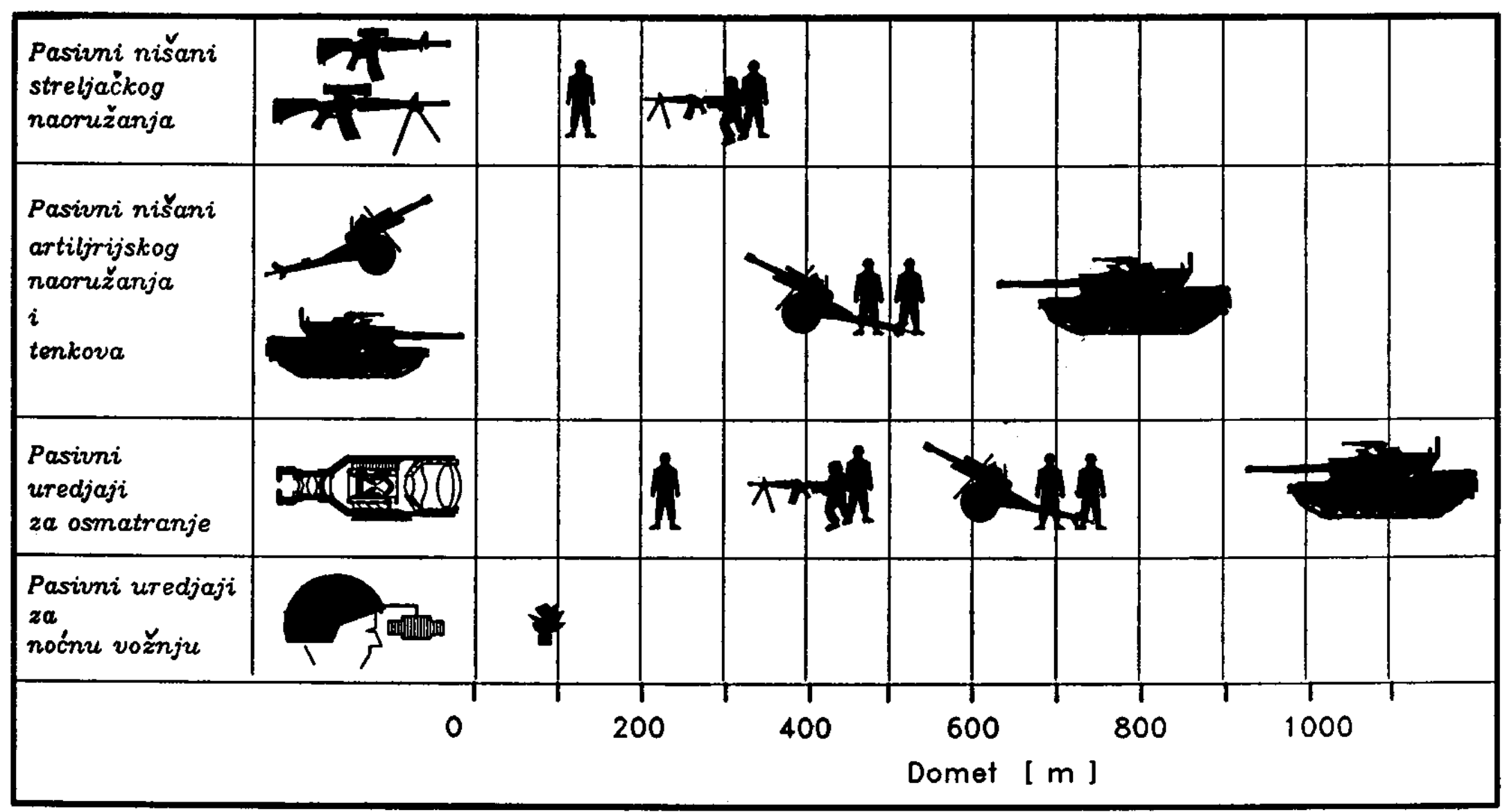

Sl. 15 Prosečni domet nekih pasivnih spra va u normalnim meteorološkim uslovima

postiže se: pravovremeno otkrivanje pokreta protivnika, usporavanje tempa napada protivnika dejstvom po težištu napada, sprečavanje iznenađenja, smanjenje opasnosti od dejstva ubačenih grupa, i dr.

Svojstva pasivnih sprava moraju biti poznata komandantima jedinica, kako pri obuci, tako i pri planiranju borbenih dejstava, pa čak i pri razvoju doktrine upotrebe oružanih snaga. Poseban značaj posvećuje se upoznavanju sa mogućnostima protivnika za upotrebu pasivnih sprava pri bezbednosnim procenama protivnika.

Sve to ukazuje da je potrebno posvetiti značajnu pažnju primeni pasivnih sprava, kako na taktičkom nivou (opremanje, obuka), tako i na strategijskom nivou (planiranje istraživanja, razvoja i opremanja jedinica). Za postizanje maksimalnih efekata primene pasivnih uređaja, moraju se dobro poznavati karakteristike uređaja kojima se raspolaže kao i prisustvo nepovoljnih uticaja $u$ prostoru i $u$ vremenu upotrebe jedinica, još u fazi planiranja borbenih dejstava.

\section{Specifičnosti konstrukcije i održavanja pasivnih sprava}

$\mathrm{Na}$ konstrukciju, upotrebu i održavanje pasivnih sprava utiče više faktora, od kojih su najznačajniji:

* Karakteristike pojačavača slike, kao što su:

- optoelektronske karakteristike (razlaganje, strujna osetljivost fotokatode, pojačanje) utiču na optoelektronske karakteristike sprave (domet);

- visoki napon napajanja cevi utiče na zahteve za hermetičnost uređaja i posebne mere za zaštitu od proboja visokog napona (izolacija);

- degradacija karakteristika fotokatode pri izlaganju visokom nivou osvetljenja i visokoj temperaturi zahteva preduzimanje posebnih mera pri konstrukciji, upotrebi i održavanju sprava radi sprečavanja pojava ekscesnih situacija;

- degradacija karakteristika fotokatode pri starenju, što uzrokuje potrebu za preduzimanje posebnih mera pri dugotrajnom skladištenju;

- relativno visoka cena (oko 2000 $\$$ ) zahteva da se vodi računa o raciona- 
lizaciji utroška i resursa rezervnih pojačavačkih cevi.

* Karakteristike elemenata optičkog sistema, kao što su lomljivost i negativan uticaj nečistoće.

* Karakteristike spoljašnjih izvora električne energije (akumulatori, baterije), kao što su kapacitet, trajnost i stabilnost.

* Specifičnosti podešavanja i montaže, kao što su visoki zahtevi za čistoću prostora (uticaj vlage i prašine) i preciznost podešavanja (podešenost fokusa, usaglašenost podsklopova, primena specijalnih pribora, alata i postupaka).

Ovi faktori uslovljavaju da se $u$ procesu projektovanja i izrade, upotrebe, održavanja i skladištenja mora voditi posebna briga da bi se obezbedio potreban nivo ispravnosti i gotovosti za upotrebu, kao i ukupnih efekata upotrebe.

\section{Projektovanje i izrada}

U procesu projektovanja i izrade pasivnih sprava moraju biti korišćeni osnovni principi koji doprinose jeftinijoj proizvodnji i jednostavnijem održavanju, kroz primenu agregatnog principa $u$ organizaciji održavanja, kao što su:

* modularnost konstrukcije, tako da odabrani podsklopovi čine celinu sa jasno definisanim karakteristikama (moduli) koji omogućuju jednostavno povezivanje sa drugim modulima $u$ funkcionalnu celinu bez posebnih zahteva za dopunska vodešavanja pri montaži;

* kompatibilnost konstrukcije, koja treba da omogući jednostavnu zamenu uređaja u sistemu u kome se koristi ili jednostavnu zamenu modula uređaja istog tipa, i korišćenje istih modula $u$ više različitih uređaja;

* primena elektronike, koja treba da omogući funkciju samotestiranja ispravnosti uređaja $i$ pravovremenu signalizaciju kvarova ili istrošenosti potrošivih podsklopova. Pored toga, pri- menom rešenja koja pruža savremeni stepen razvoja elektronike, treba omogućiti automatizaciju zaštite uređaja od kritičnih uticaja koji izazivaju trajnu degradaciju karakteristika (npr. zaštita od izlaganja fotokatode jakom osvetljavanju ili zaštita od pregrejavanja fotokatode);

* povećavanje pouzdanosti, koje se može postići primenom mera i konstrukcionih rešenja koja doprinose dužem radnom veku (povećanje srednjeg vremena između otkaza-MTBF), kao što su: redundacija (udvajanje) kritičnih podsklopova, korišćenje komponenti sa većim stepenom pouzdanosti, primenom procedure razrade $u$ završnoj kontroli kvaliteta, i sl.

Uporedo sa primenom ovih opštih principa pri konstrukciji i izradi pasivnih sprava mora se voditi računa $i$ o:

- optimizaciji optoelektronskih karakteristika uređaja u pogledu zahtevanog dometa (izbor cevi, izbor i konstrukcija objektiva i sl.);

- izolaciji električnih vodova i zaštiti od proboja visokog napona;

- obezbeđenju hermetičnosti modula i sprave u celini;

- obezbeđenju zaštite unutrašnjosti sprave od prisustva vlage (primena isušivača);

- lakoj rasklopivosti uređaja (primena spojeva sa »0 « zaptivkama);

- zaštiti fotokatode od izlaganja dnevnoj svetlosti, posebno kod kombinovanih dnevno-noćnih sprava;

- zaštiti od priključenja izvora sa neadekvatnim polaritetom;

- mogućnosti priklịučivanja alternativnih izvora napajanja;

- signalizaciji istrošenosti izvora za napajanje;

- zaštiti lomljivih podsklopova i komponenti od mehaničkih uticaja koji se mogu javiti pri eksploataciji (primena elastičnịh spojeva koji amortizuju mehanička dejstva ili kompenzuju pojave deformacija u spojevima). 


\section{Upotreba pasivnih sprava}

Pri upotrebi pasivnih sprava (rukovanje i osnovno održavanje) treba voditi računa o sledećem:

- redovno i pravovremeno čišćenje spoljašnjih optičkih površina;

- $u$ dnevnim uslovima ne sme biti uključeno napajanje cevi a fotokatoda, odnosno ulazni otvor objektiva sprave mora biti zaštićen od dejstva dnevne svetlosti;

- pravovremena kontrola i zamena izvora za napajanje, kao i provera ispravnosti konektora i prekidača;

- kontrolá ispravnosti i pravovremena zamena uloška isušivača;

- pažljivo postupanje pri montaži i demontaži sprava;

- čuvanje sprava u zamračenim i hermetizovanim kutijama, ukoliko se ne koriste.

Kako je za održavanje ispravnosti sprave najkritičnija opasnost od izlaganja fotokatode povećanom nivou osetljivosti, proizvođači pojačavačkih cevi ispituju i deklarišu dozvoljene nivoe osvetljaja i trajanja izlaganja koji bitno ne ugrožavaju vék trajanja fotokatode. $\mathrm{Za}$ cevi I generacije ne dozvoljava se osetljivost fotokatode veća od 25 luksa, a dozvoljava se kratko trajna osvetljenost 5 do 25 luksa u trajanju 10 sekundi ili 0,5 do 5 luksa u trajanju 60 sekundi ili 50 do 500 mililuksa $u$ trajanju $10 \mathrm{~min}$, a pri osvetljenosti fotokatode manjoj od 50 mililuksa vek cevi je 2000 sati. Cevi druge generacije su nešto manje otporne na degradaciju pri izlaganju povišenoj osvetljenosti i za njih se deklariše da trajno mogu biti izloženi osvetljenosti do 10 mililuksa.

\section{Remont pasivnih sprava}

Za planiranje i organizaciju remonta i opravki na svim nivoima održavanja značajno je obezbeđenje osnovnih preduslova:

* organizacija opravki na agregatnom principu (zamena sprave isprav- nom $i$ remont $u$ specijalizovanim radionicama), što znači da treba obezbediti i ešalonirati zadovoljavajući resurs rezervnih sprava;

* remont pasivnih sprava mora da se obavlja u specijalizovanim radionicama u kojima je obezbeđen čist (bez vlage $i$ prašine) $i$ zamračen prostor, a koje su opremljene specijalnim alatima i priborom za podešavanje i kontrolu ispravnosti sprave i podsklopova. Radionicu opslužuje specijalno obučen i kvalifikovan kadar;

* srednji remont (na nivou zamene modula) može se organizovati i $u$ pokretnim radionicama;

* generalni remont (uz intervencije na modulima npr. remont pojačavača slike) najefikasnije se sprovodi u stacionarnim radionicama ili kod proizvođača.

Pri remontu posebno treba voditi računa o sledećem:

- rasklapanje i sklapanje sprava dozvoljeno je samo $u$ čistom prostoru (bez vlage i prašine);

- demontaža pojačavačke cevi dozvoljena je isključivo kada je cev potpuno razelektrisana (po proteku najmanje 15 minuta od isključenja napajanja);

- pri sklapanju posebno voditi računa o hermetičnosti spojeva;

- pri remontu se mora voditi računa o ispravnosti $i$ istrošenosti resursa upotrebe pojačavačke cevi.

\section{Skladištenje i konzervacija}

Pri skladištenju i konzervaciji pasivnih sprava mora se obezbediti:

* suva i čista atmosfera (najpogodnije je vakuumsko pakovanje sa isušivačem vazduha);

* za dugotrajno skladištenje sprava i pojačavačkih cevi - primena frizera (temperatura $-20^{\circ} \mathrm{C}$ ) zbog produženja životnog veka cevi;

* čuvanje u zamračenom prostoru;

* povremeno uključivanje pojačavača slike (kondicioniranje) zbog regeneracije fotokatode. 


\section{Zaključak}

Primena pasivnih sprava za izvođenje borbenih dejstava noću i u uslovima ograničene vidljivosti omogućuje znatno povećanje efikasnosti borbenih dejstava u ovim uslovima i uzrokovala je izmene $u$ taktici i doktrini upotrebe oružanih snaga, proširujući vremenski resurs upotrebe i povećavajući dinamiku izvođenja borbenih dejstava. Zbog toga se, $u$ programiranju istraživanja i razvoja, i planiranju opremanja i upotrebe oružanih snaga, mora posvetiti posebna pažnja, kako ostvarivanju mogućnosti što šire primene pasivnih sprava, tako i poznavanju uslova koji ograničavaju njihovu primenu.

Faktori koji ograničavaju ukupne mogućnosti upotrebe pasivnih sprava su brojni, pa se stoga mora posvetiti posebna pažnja obrazovanju starešina i obuci jedinica za primenu pasivnih sprava kako bi se omogućilo optimalno iskorišćenje mogućnosti koje pružaju. Kako se pasivne sprave relativno kratko koriste, $u$ jedinicama ima dosta problema $u$ iskorišćenju ukupnih mogućnosti koje njihova upotreba pruža, kao i veliki nedostaci u organizaciji održavanja. Deo problema vezanih za upotrebu i održavanje pasivnih sprava može se lakše rešiti kroz bliži kontakt raz-

\section{Literatura:}

[1] Schagen P.: »Image converters and intensiffers (1975), Journal of Physics E.: Scientific Instruments, vol. 8, str. 153-160

[2] Csorba I. P: "Recent Advancement in the Image Intensification: The Generation 3 Wafer Tubex, (1979), Applied Optics, vol. 18, No1, str. 2440-2444

[3] Gardiner F. T. (ed): "Electro-optics Handbook», (1965), RCA Commercial Engineering Harisson

[4] Engstrom R. W.: »Photomultiplier Handbook«, (1980), RCA Corporation, Lancaster

[5] Wolfe W. L., Zissis G. J (ed.) "The Infrared Handbook火, (1978), Office of Naval Reseach, Department of Navy, Vashington

[6] Barrcate F., King D.: »Night Vision Tybes and Solid State Devices,, (1984), Special Electronics, $\mathrm{No} 3 / 84$, str. $45-41$

[7] Bjork L. i sar.: Jolictic System Design Maximones Night Vision Device Pertormancek, (1983), Military Electronics/Countermeasures. No $\mathrm{feb} / 83$, str. $34-39$

[8] Beach J. B.: »Atmospheric Effects on EO/IR Propagation«, (1980), Defence Electronics, No apr $/ 80$, str. $77-85$

[9] Gourley S. R.: »Piercing the Darknesse, (1989), Defence Electronics, No jul/89, str. 85-89 vojnih organa i jedinica korisnika (predavanja, demonstracije mogućnosti, tehničke informacije, nastavni filmovi, i dr.)

Termovizija ne isključuje dalji razvoj i primenu pasivnih sprava. Naprotiv, ovi sistemi za primenu $u$ otežanim uslovima vidljivosti međusobno se dobro dopunjuju.

Kako je ukupna cena pasivnih sprava visoka, iako mnogo niža nego za termovizijske uređaje, a i tehnološka složenost takva da ograničava rasprostranjenost uređaja koji se primenjuju u jedinicama, ne sme se zanemariti ni primena drugih sredstava i postupaka koji podržavaju izvođenje borbenih dejstava noću (taktički postupci u noćnim uslovima, primena veštačkih izvora zračenja - reflektori, pirotehnička osvetljavajuća i obeležavajuća sredstva, i dr).

Složenost i osetljivost pasivnih sprava zahteva da se u procesu projektovanja, upotrebe, održavanja i skladištenja koristi niz posebnih postupaka koji doprinose ukupnoj ispravnosti sprava i dugotrajnosti uǵrađenih komponenti. Obuka jedinica u uslovima primene pasivnih sprava, kako u sopstvenim jedinicama tako i u jedinicama protivnika, mora biti prilagođena specifičnostima upotrebe i mogućnosti pasivnih sprava.

[10] Parry D.: „Night Vision Techniques and Equipmente, (1989), Armada International, No 2/89, str. $64-72$

[11] Braybrook R.: "A Survey of Modern Night Vision Techniques, (1984), Armada International, No $3 / 84$, str. $36-46$

[12] Kuhl W.: Night Vision - Vital Aid to the Modern Army\&, (1983), Armada International, Special II, No $5 / 83$

[13] ... : »Day Sights, Image Intensifiers, Thermal Imagers and Laser Range-finders: A review of British sighting equipment «, (1979), DEFENCE MATERIEL, No jan-feb/79, str. 2-22

[14] ...: »Obscuration and Night Vision Systemse, (1985), DEFEICE MATERIEL, No sep-okt/85, str. $169-172$

[15] Bhave B. D, Monga J.C.: »A Nomograph for the Estimation of the Field Performance of Active Night Viewing Systems«, (1982), Optics and Laser Technology, No jun/82, str. 155-159

[16] Monga J. C., Bhave B. D.: «Spectral Matching Consideration of Low Light Level Imaging Systems«, (1984), Applied Op:ics, vol. 23, No 10. str. 1628-1631

[17] Holl H.: Fundamentals of Visibility<, (1977), NTIS ADA 040836. 